\title{
Entrepreneurial Intention in Doing Information- Related Business and Comparison on Gender, Family, Discipline of Study and Family Income
}

\author{
Nurhidayah Nasharudin, Norliya Ahmad Kassim and Nor Famiza Tarsik
}

Faculty of Information Management, Universiti Teknologi MARA (UiTM), Selangor, Malaysia

Correspondence should be addressed to: Nurhidayah Nasharudin; nurhidayah204@kelantan.uitm.edu.my

Received 12 January 2013; Accepted 12 June 2013; Published 30 October 2013

Academic Editor: Maria Grosu

Copyright (C) 2013 Nurhidayah Nasharudin, Norliya Ahmad Kassim and Nor Famiza Tarsik. Distributed under Creative Commons CC-BY 3.0

\begin{abstract}
The objective of this study is to identify the level of students' entrepreneurial intention in doing information-related business and to compare the entrepreneurial intention between gender, role of family background, discipline of study and family income. Using a quantitative approach of study, questionnaires were distributed randomly to 175 postgraduate students of Faculty of Information Management, Universiti Teknologi MARA (UiTM), Malaysia. The finding revealed that students were quite positive towards their intention in doing information-related business. The mean score was highest for I will make every effort to start and run my own information-related business (mean=3.32) followed by If I had the opportunity and resources, I'd like to start an informationrelated business (3.29). However there was no evidence of difference regarding entrepreneurial intention between gender, role of family background, discipline of study and family income. The finding of this study will be useful to the management of Faculty of Information Management, other academic institutions and educators to design the entrepreneurship course for university students.
\end{abstract}

Keywords: Entrepreneurship, Entrepreneurial intention, information-related business, family background, discipline of study, family income.

\section{Introduction}

Entrepreneurship is highly regarded as one of the most significant factors that contribute to the nation's economic development, growth and prosperity. A profession in entrepreneurship offers significant opportunities for individuals to achieve wealth and profit by contributing to job creation, innovation, novelty and economic growth. This may also help in solving unemployment problems particularly among graduates. With the present current economic situation, graduates are encouraged to be involved in entrepreneurship. Every year, universities are producing an increase number of graduates and they faced competition for jobs in the graduate labor market. Today's students are tomorrow's potential

Cite this Article as: Nurhidayah Nasharudin, Norliya Ahmad Kassim and Nor Famiza Tarsik (2013), "Entrepreneurial Intention in Doing Information- Related Business and Comparison on Gender, Family, Discipline of Study and Family Income," Journal of Southeast Asian Research, Vol. 2013 (2013), Article ID 202871, DOI: $10.5171 / 2013.202871$ 
entrepreneurs, which may explain why a strong interest in entrepreneurship education has emerged throughout the universities in Malaysia and growing number of universities offer courses and programs in entrepreneurship.

University students are encouraged to pursue a career in self/small business employment (Nabi and Holden, 2008). With the economic pressure, students need to change their attitude and behavior rather than rely on government's initiative. Due to that, everyone is encouraged to be selfemployed and become an entrepreneur. They should have the intention to start-up the business on their interest or related field. Business or entrepreneurship's career offers big opportunities to achieve financial independence and offer plenty of benefits for career development, job innovation and creation.

Intention is a key concept when it comes to understanding the reason for individual's careers (Franco, Haase and Lautenschlager, 2010). This is particularly true for explaining the decision to startup new venture, where the entrepreneurial intention has been considered a chief element (Bird, 1988). The Theory of Planned Behavior (TPB) (Ajzen, 1991) and Shapero and Sokol Model (Shapero and Sokol, 1982) are used to relate with the intention in doing information-related business among students. These theories identify the importance of assessing the amount of control an individual has over behaviors and attitudes (perceived behavioral control). The components of the model consist of intention, attitude towards behavior, subjective norms, and perceived behavioral control. This model tries to pointout some element such as attitude, subjective norms and behavior that leads to individual intention.

In Malaysia, however, studies examining entrepreneurship intention among students of information background is scarce (Mohammad et al., 2009). The other issue is lack of involvement from the information science or information management professionals who are involved in the information-related business, for example, establishing a database of abstracts and citations for scholarly article journal, or book publisher, book vendor, information consultant services, Internet entrepreneur, and so on. The area of business on information is more monopolized by business people rather than those from information science and information management background.

From all the above perspectives, this study explores the intention of postgraduate students at the Faculty of Information Management, Universiti Teknologi MARA (UiTM), Malaysia whether they had the intention to become entrepreneur in information-related business.

\section{Literature Review}

Intention refers to the behaviors that lead people or indicate how hard people are willing to try and their efforts that they try to plan in order to carry out the behavior (Ajzen, 1991; Liu, Li and Feng, 2011). In theoretical terms, new venture creation is an intentional act that involves repeated attempts to exercise control over the progression in a particular domain, in order to achieve the desired outcome (Malle, 1999). Eagly and Chaiken (1993) stated that intention is a conscious plan which then leads their efforts to carry out the behavior. Shapero and Sokol (1982) mentioned that intention is more related to the perceptions of desirability and feasibility and the propensity to proceed towards opportunities.

Intentions are assumed to capture the motivational factors that influence a behavior; they are indications of how hard people are willing and eager to try, of how much of an effort they are setting up to exert in order to carry out the behavior (Ajzen, 1991; Atinc, 2011; Pak, 2011). Krueger et al., 
(2000) had conducted a study regarding intention, which is related to human's attitudes, willingness and so on. Many researches had been conducted based on intention models such as The Theory of Planned Behaviour [Ajzen, 1991; Bird, 1988; Shapero and Sokol, 1982).

Additionally, the social attitude and personality trait have played an important role to predict and explain human behavior (Campbell, 1963; Sherman and Fazio, 1983). The Shapero and Sokol Model (Shapero and Sokol, 1982) were studied based around intentions that translate to action to start the business and became entrepreneur (Iakovleva, 2011; Nabi and Holden, 2008). Entrepreneurship intention often involves inner guts, aspiration and the sense to stand on one's feet (Zahariah, et al., 2010). They also stated that to become an entrepreneur, people should have entrepreneurship intention that lead to the action of personal attitudes towards the outcomes of that actions and individual's self-efficacy. This is supported by Bird (1988), when he mentioned intentionality is a main perception when it comes to accepting the reasons for individuals' careers. This is particularly significant for clearing up the decision to initiate up a new venture, where the entrepreneurial intention has been considered a chief element.

With the financial downturn in economic trends today, many citizens already think to change their economic environment and economic structure to sustain in daily life. They tend to explore in business venture such as business enterprise, small-medium firm and so on. The development of technology brings people to market the technology's tools and their expertise and commercialize it to the customers. Yuan, Ming and Chen (1999) mentioned that enterprises should be equipped and prepared with rapid and accurate analytical capabilities on business information so that they can foresee the future. $\mathrm{He}$ also highlighted that the need of information become crucial necessities when enterprise or business firm are in need of informationrelated business, so that they rely more on information professionals that have the expertise, expert or professional organizations for the collection, compilation and analysis of information.

Information-related business phenomena has become demanding nowadays. This is because people really need information and relies on it for their daily basis and decisionmaking. They can afford it as long as it fulfills their information need. Yuan, Ming and Chen (1999) stated that the demand for business information services starts to boom. It is crucial for business information service providers to understand the demand motives of major clients, their interest and how they evaluate such services so as to build up services that meet the clients' prospect. In Africa, graduates of various disciplines, including library and information science have found it difficult to find the jobs and led many graduates to take jobs for example information related jobs other than library jobs (Affolabi, 1997). Besides, it was recommended that the Department of Library and Information Science in the country must make provision for the training of information-related job other than relying on the library and information center career only (Agumanu, 1986). They also have a propensity to become a book publisher, book vendor, information consultant, and Internet's entrepreneur and so on to become self-employed. Self-employed professionals are skilled information retrieval and delivery who markets his or research services commercially, usually on a freelance basis. Information brokers are organized in the Association of Independent Information Professionals (AIIP) and Independent Librarian's Exchange (ILEX) (Reitz, 2010).

\section{Research Questions}

The research questions put forward are:

1. What is the level of students' entrepreneurial intention in doing information-related business? 
2. Are there differences regarding students' entrepreneurial intention in doing information-related business between gender, roles of family background, discipline of study and students' family income?

\section{Methodology}

The populations in this study were the postgraduate students from the Faculty of Information Management, UiTM, Malaysia. They were from Master in Information Management, Master in Knowledge Management and Master in Library Science program. There were 327 students for the whole Master's program. For the sampling technique, this study used Krejcie and Morgan's (1970) sampling model to select the sample size. The sample size for this study was 175 postgraduate students from the Faculty of Information Management, UiTM, Shah Alam, Selangor. The questionnaire was adapted from various instruments such as The Theory of Planned Behavior Model (Ajzen, 1991); Shapero and Sokol Model (Shapero and Sokol Model, 1982) and other variables in the questionnaire were obtained from various literatures on entrepreneurship intention (Krejcie and Morgan, 1970). The questionnaires were distributed randomly to 175 postgraduate students of Faculty of Information Management, UiTM, Shah Alam, and Selangor. The response rate was $78 \%$ (136). Combinations of descriptive and inferential statistics were done in analyzing the data from this study. Mean ranking and standard deviation were performed to analyze the descriptive part of the analysis. For the inferential statistics, the independent samples $t$-test and one-way analysis of variance were conducted.

\section{Results}

\section{Profile of Respondents}

Out of the total number of respondents asked, majority (104 or $76.5 \%$ ) were female postgraduates, while $32(23.5 \%)$ were male. A total of $54(39.7 \%)$ of the respondents were from Master in Knowledge Management program, followed by one-third (45 or 33.1\%) from Master in Library Science and 37 (27.2\%) from Master in Information Management program. Slightly more than a third (47 or $34.6 \%$ ) of the respondents came from a family who were not involved in business, followed by 31 (22.8\%) of the respondents whose siblings were involved in business. Respondents whose parents were already involved in business accounts for 30 (22.1\%) while the remaining 27 (19.9\%) had cousins, in-laws and uncles who are already involved in it.

\section{Reliability and Normality Test}

Reliability test was carried out to test the consistency of the internal scale on entrepreneurial intention. The scale is reliable as Cronbach's Alpha value is 0.964 . Test of normality was carried out to check whether distributions of the data for the variables are normally distributed. This is because all parametric tests require the variables analyzed to be normally distributed. The scales for all data were normal as all Kolmogorov-Smirnov Test for $Z$-values are significant at $1 \%$ level $(p=0.00<0.01)$.

\section{Level of Entrepreneurial Intention}

In order to examine respondents' opinion on their entrepreneurial intention in doing information-related business, statements related to the entrepreneurial intention were evaluated. In this study, a score of "1" represents "strongly disagree" and a score of "5" represents for "strongly agree". This study has taken the position that any score in excess of 3.0 shows that respondents inclined to agree with the particular statement, while overall mean score in excess of 3 indicates that respondents inclined to agree with the statement as a whole. 
Table 1 shows that the overall mean score of 3.19 indicates that respondents quite agreed with the statement on entrepreneurial intention. The mean scores for all items are between 3.32 to 3.07 and this indicates that they quite agree with all the statements. Among the twelve statements, the mean score is highest for I will make every effort to start and run my own information-related business (mean=3.32) followed by If I had the opportunity and resources, I'd like to start an information-related business. Although the statement on I've thought about starting my own business especially in information-related business (mean=3.07) is the lowest, it still indicates that respondents are positive towards their intention to become entrepreneurs.

Table 1: Mean Score for Entrepreneurial Intention

\begin{tabular}{|l|c|c|}
\hline \multicolumn{1}{|c|}{ Component of entrepreneurial intention } & Mean & $\begin{array}{c}\text { Std } \\
\text { deviation }\end{array}$ \\
\hline $\begin{array}{l}\text { 1. I will make every effort to start and run my own information- } \\
\text { related business }\end{array}$ & 3.32 & 1.009 \\
\hline $\begin{array}{l}\text { 2. If I had the opportunity and resources, I'd like to start an } \\
\text { information-related business }\end{array}$ & 3.29 & 0.952 \\
\hline $\begin{array}{l}\text { 3. I am determined to create an information-related business in } \\
\text { the future }\end{array}$ & 3.24 & 0.960 \\
\hline $\begin{array}{l}\text { 4. I have the business intention to start an information-related } \\
\text { business some day }\end{array}$ & 3.23 & 0.911 \\
\hline $\begin{array}{l}\text { 5. I've thought that I'll start my own information-related } \\
\text { business in the next 10 years }\end{array}$ & 3.21 & 1.037 \\
\hline $\begin{array}{l}\text { 6. I will make every effort to start and run an information- } \\
\text { related business in the future }\end{array}$ & 3.18 & 0.888 \\
\hline $\begin{array}{l}\text { 7. I have very seriously thought of starting an information- } \\
\text { related business }\end{array}$ & 3.16 & 0.975 \\
\hline 8. My professional goal is to become an entrepreneur & 3.14 & 1.027 \\
\hline 9. I am ready to do anything to be an entrepreneur & 3.13 & 0.925 \\
\hline $\begin{array}{l}\text { 10. I've thought that I'll start my own information-related } \\
\text { business in the next 5 years }\end{array}$ & 3.13 & 1.053 \\
\hline $\begin{array}{l}\text { 11. Now, I really understand the spectrum of information-related } \\
\text { business }\end{array}$ & 3.12 & 0.967 \\
\hline $\begin{array}{l}\text { 12. I've thought about starting my own business especially in } \\
\text { information-related business }\end{array}$ & 3.07 & 0.979 \\
\hline Overall statement & 3.19 & 0.973 \\
\hline
\end{tabular}

\section{Differences Regarding Students' Entrepreneurial Intention in Doing Information-Related Business among Selected Demographic Profile}

This section determines whether there are significant differences regarding students' entrepreneurial intention in doing information-related business between gender, roles of family background, discipline of study and students' family income. To compare the differences regarding students' entrepreneurial intention in doing information-related between genders, the independent samples $t$-test was used as the distribution of the mean scores is normal. The results are summarized in Table 2 . 
Table 2: Independent Samples $t$-Test Results on Students' Entrepreneurial Intention in Doing Information-Related Business between Genders

\begin{tabular}{|l|c|c|c|c|c|}
\hline \multicolumn{1}{|c|}{ Item } & \multicolumn{2}{|l|}{ Sample size } & $\begin{array}{c}\text { Mean } \\
\text { score }\end{array}$ & $\begin{array}{c}\boldsymbol{t} \text { - } \\
\text { statistics }\end{array}$ & $\boldsymbol{p}$-value \\
\hline $\begin{array}{l}\text { 1. Entrepreneurial } \\
\text { intention }\end{array}$ & $\begin{array}{c}\text { Female } \\
\text { Male }\end{array}$ & $\begin{array}{c}10 \\
4\end{array}$ & 3.0641 & -0.900 & 0.370 \\
& \multicolumn{2}{|c|}{136} & & & \\
\hline Total $(n)$ & & & & \\
\hline
\end{tabular}

Table 2 presents the results of the comparison of mean on students' entrepreneurial intention in doing information-related business between genders. The results show on average, the level of entrepreneurial intention in doing information-related business between gender are statistically not significant ( $p$ value $=0.370$ ) since the $5 \%$ probability level is $p$-value $>0.05$. It is concluded that, the level of entrepreneurial intention in doing information-related business is similar regardless of which gender group the respondents belong.

Analysis on the differences in the level of entrepreneurial intention among roles of family background, discipline of study and students' family income is carried-out using one-way analysis of variance (ANOVA) since the respective variables are normally distributed. The results are presented and discussed in the succeeding section.

Table 3: Summary Statistics of ANOVA Test on Students' Entrepreneurial Intention in Doing Information- Related Business between Roles of Family Background

\begin{tabular}{|l|c|c|c|c|c|}
\hline & $\begin{array}{c}\text { Sum of } \\
\text { Squares }\end{array}$ & df & Mean Square & F & Sig. \\
\hline $\begin{array}{l}\text { Overall Mean } \\
\text { Between } \\
\text { Groups }\end{array}$ & 0.390 & 3 & 0.130 & 0.231 & 0.874 \\
$\begin{array}{l}\text { Entrepreneu } \\
\text { rial Within } \\
\text { Groups } \\
\begin{array}{l}\text { Intention } \\
\text { Total }\end{array}\end{array}$ & 74.279 & 132 & 0.563 & & \\
\hline
\end{tabular}

Table 3 presents the results of the comparison of mean on entrepreneurial intention between roles of family background. The results show on average, the level of entrepreneurial intention in doing information-related business among the respondents from the three groups of family background are statistically not significant $(p$-value $=0.874)$ since the $5 \%$ probability level is $p$-value $>0.05$. It is concluded that, the level of entrepreneurial intention in doing information-related business do not differ regardless of which roles of family background group the respondents belong. 
Table 4: Summary Statistics of ANOVA Test on Students' Entrepreneurial Intention in Doing Information-Related Business among Disciplines of Study

\begin{tabular}{|ll|c|c|c|c|c|}
\hline & & Sum of Squares & df & $\begin{array}{c}\text { Mean } \\
\text { Square }\end{array}$ & F & Sig. \\
\hline Overall Mean & Between Groups & 0.540 & 2 & 0.270 & 0.484 & 0.617 \\
Entrepreneurial & Within Groups & 74.129 & 133 & 0.557 & & \\
Intention & Total & 74.669 & 135 & & & \\
\hline
\end{tabular}

Table 4 presents the results of the comparison of mean on entrepreneurial intention among disciplines of study. The results show on average, the level of entrepreneurial intention in doing information-related business among the respondents from the three groups of program is statistically not significant ( $p$ value $=0.617$ ) since the $5 \%$ probability level is $p$-value $>0.05$. It is concluded that, the level of entrepreneurial intention in doing information-related business is similar regardless of which disciplines of study group the respondents belong.

Table 5: Summary Statistics of ANOVA Test on Students' Entrepreneurial Intention in Doing Information-Related Business among Students' Family Income

\begin{tabular}{|ll|c|c|c|c|c|}
\hline & $\begin{array}{c}\text { Sum of } \\
\text { Squares }\end{array}$ & df & $\begin{array}{c}\text { Mean } \\
\text { Square }\end{array}$ & F & Sig. \\
\hline Overall & Between Groups & 2.088 & 4 & 0.522 & 0.935 & 0.446 \\
Mean & Within Groups & 72.581 & 130 & 0.558 & & \\
Entrepreneu & Total & 74.669 & 134 & & & \\
rial & & & & & \\
Intention & & & & & \\
\hline
\end{tabular}

Table 5 presents the results of the comparison of mean on entrepreneurial intention among students' family income. The results show on average, the level of entrepreneurial intention in doing information-related business among the respondents from the five groups of students' family income are statistically not significant $(p$-value $=0.446)$ since the $5 \%$ probability level is $p$-value $>0.05$. It is concluded that, the level of entrepreneurial intention in doing information-related business is the same despite of which students' family income group the respondents belong.

\section{Discussions and Conclusions}

This paper has answered the research questions on students' entrepreneurial intention in doing information-related business and to see if there are differences regarding their entrepreneurial intention in doing information-related business between gender, roles of family background, discipline of study and students' family income. Overall, students quite agreed that they have the entrepreneurial intention to start business venture. The overall mean score on their opinion on entrepreneurial intention is 3.19 indicating that they quite agreed with the statements as a whole. Generally, similarity was found regarding students' entrepreneurial intention in doing information-related business between genders, among roles of family background and disciplines of study and students' family income. This implies that, students seriously thought of starting business and will make every effort to start and run their own information-related business in order to get a 
higher income. Both males and females who come from different background had similar understanding and perception on entrepreneurship, which is a career as selfemployed that offers big opportunities to achieve financial independence and gave benefits for growth, innovation and also job creation. Since the students' educational levels are the same which is Master's level, their intention to become entrepreneur is the same regardless of which genders, roles of family background, disciplines of study and students' family income group they belong. Therefore, their behavior, attitudes, thought and belief are similar with each other.

Academicians need to play a significant role in encouraging more students to become entrepreneurs by providing more awareness on the benefits of becoming entrepreneurs and in turn, contributing to the growth of the country's economies and global competitiveness. To improve entrepreneurial intention among students, entreprenuership education in the information studies' curriculum should be introduced to enhance the skills and knowledge on entrepreneurship. Entrepreneurship education should be made compulsory to all students. By doing this, it is hoped that more entrepreneurs will be produced after they leave the university. Besides, the Faculty can introduce more entrepreneurship seminars and motivation courses to interested students so that they are more exposed to be entrepreneurs. In addition, the UiTM Alumni can also make use of alumnis who are entrepreneurs to give talk in sharing their experiences and at the same time able to motivate these students. This study will have a profound impact on making recommendations particularly to the management of Faculty of Information Management and other academic institutions and educators to design the entrepreneurship course among university students. Besides, it will give an idea to Malaysian Academy of SME \& Entrepreneurship Development (MASMED) of UiTM to develop entrepreneurial activities or short courses among students.

\section{Acknowledgment}

This study was supported by Universiti Teknologi MARA (UiTM), Shah Alam, Malaysia. The researchers wished to thank UiTM and all respondents who had participated in the survey.

\section{References}

Affolabi, M. (1997). “Career Opportunities for Library and Information Science Professionals in Africa," Librarian Career Development, 2 (2), 23-32.

Agumanu, J. N. (1986). 'Alternative Uses of Library Education,' Paper presented at the 3rd National Conference on Library Education, Owerri, 15-16 December 1986, 12.

Ajzen, I. (1991). "The Theory of Planned Behaviour," Organizational Behaviour and Human Decision Processes, 50, 179-211.

Ali, A., Topping, K. J. \& Tariq, R. H. (2011). "Entrepreneurial Attitudes among Potential Entrepreneurs," Pak, J. C.Soc. Sci., 5 (1), 1246.

Atinc, G. M. (2011). “Detrimental Effects of Interventions with the Corporate Governance Mechanisme of Young Entrepreneurial Firms," Doctorate Thesis, Louisiana Tech University.

Bird, B. (1988). "Implementing Entrepreneurial Ideas: The Case for Intention," The Academy of Management Review, 13 (3), 29-48.

Campbell, D. T. (1963). "Social Attitudes and Other Acquired Behavioral Dispositions," Psychology, 6, 94-172. 
Eagly, A. H. \& Chaiken, S. (1993). The Psychology of Attitudes, Harcourt Brace Jovanovich, Fort Worth.

Franco, M., Haase, H. \& Lautenschlager, A. (2010). "Students' Entrepreneurial Intentions: An Inter-Regional Comparison," Education + Training, 52 (4), 260-275.

Iakovleva, T., Kolvereid, L. \& Stephan, U. (2011). "Entrepreneurial Intentions in Developing and Developed Countries," Education + Training, 53 (5), 353 - 370.

Krejcie, R. V. \& Morgan, D. W. (1970). "Determining Sample Size for Research Activities," Educational and Psychological Measurement, 30, 607-610.

Krueger, N. F., Reilly, M. D. \& Carsrud, A. L. (2000). "Competing Models of Entrepreneurial Intentions," Journal of Business Venturing, 15 (2), 411-32.

Malle, B. F. (1999). "How People Explain Behaviour: A New Theoretical Framework," Personality and Social Psychology Review, 3 (1), 23-48.

Mohammad, I. et al. (2009). 'Entrepreneurial Intention among Malaysian Undergraduate,' International Journal Intention of Business and Management, 4 (10), 54-60.

Nabi, G. \& Holden, R. (2008). "Graduates Entrepreneurship: Intentions, Education and Training," Education+Training, 50 (7), 545551.

Reitz, J. M. (2010). 'Dictionary for Library and Information Science,' California, Libraries Unlimited.

Shao-hui, L., Ping, L. \& Peng-peng, F. (2011). "Mediation and Moderated Mediation in the Relationship among Entrepreneurial SelfEfficacy, Entrepreneurial Intention, Entrepreneurial Attitude and Role Models," Paper presented at the 18th International Conference on Management Science \& Engineering in Rome, Italy.
Shapero, A. \& Sokol, L. (1982). 'The Social Dimensions of Entrepreneurship in the Encyclopedia of Entrepreneurship,' Kent, C., Sexton, D. and Vesper, K. (eds), Englewood Cliffs, Prentice-Hall.

Sherman, S. J. \& Fazio, R. H. (1983). "Parallels between Attitudes and Traits as Predictors of Behaviour," Journal of Personality, 51, 308345.

Yuan, B. J. C., Wang, M. Y. \& Wang, C. C. (1999). "Demand for Business Information Service of Firms in Taiwan: A Case Study of Hsinchu Science-based Industrial Park and Hsinchu Industrial Park," Journal of Engineering and Technology Management, 16, 349-372.

Zain, Z. M., Akram, A. M. \& Ghani, E. K. (2010). "Entrepreneurship Intention among Malaysian Business Students," Canadian Social Science, 6 (3), 34-44. 